J. Amer. Soc. Hort. Sci. 120(3):497-504. 1995.

\title{
Gas Exchange of Citrus Seedlings at Different Temperatures, Vapor-pressure Deficits, and Soil Water Contents
}

\author{
M. Brakke ${ }^{1}$ \\ Agronomy Department, University of Florida, Gainesville, FL 32611
}

L.H. Allen, Jr.

U.S. Department of Agriculture, Agricultural Research Service, Gainesville, FL 32611

Additional index words. Poncirus trifoliata, Citrus sinensis, C. paradisii, Carrizo citrange, Swingle citrumelo, photosynthesis, transpiration, $\mathrm{CO}_{2}$ enrichment

\begin{abstract}
Midday reductions of stomatal conductance and carbon dioxide assimilation rates $\left(\mathbf{A}_{\mathrm{CO} 2}\right)$ in Citrus are typically attributed to large leaf-to-air vapor-pressure differences or high atmospheric vapor-pressure deficits (VPD). This study investigated air temperature ( $\left.T_{a}\right)$ and available soil water (ASW) level as corollary factors of atmospheric VPD that influence midday reduction of net gas exchange in citrus leaves. The influence of elevated atmospheric $\mathrm{CO}_{2}$ under conditions that inhibit net canopy $\mathbf{A}_{\mathrm{co} 2}$ was also investigated. Net canopy $\mathbf{A}_{\mathrm{co} 2}$ and evapotranspiration rates of Carrizo citrange [Poncirus trifoliata Raf x Citrus sinensis (L.) Osbeck] and Swingle citrumelo (P. trifoliata Raf x $C$. paradisii Macf.) seedlings grown in outdoor controlled-environment growth chambers were measured under two levels of $T_{a}$ with concomitant changes in VPD and two levels of atmospheric $\mathrm{CO}_{2}$ concentration, which were changed in steps over time. Cyclical depletion of ASW was allowed to occur at each set of $\mathrm{T}_{2} / \mathrm{VPD}$ and $\mathrm{CO}_{2}$ combinations. Highest net canopy Ace, rates at ambient $\mathrm{CO}_{2}$ concentration $\left(330 \mu \mathrm{mol} \cdot \mathrm{mol}^{-1}\right)$ were obtained at the low T/VPD level $(29 \mathrm{C} / 2.4 \mathrm{kPa})$ and $\mathrm{ASW}>50 \%$. Diurnal canopy $\mathrm{CO}_{2}$ uptake rates decreased at the high $\mathrm{T}_{2} / \mathrm{VPD}$ level $(37 \mathrm{C} / 3.6 \mathrm{kPa})$, and midday depression of canopy $\mathrm{A}_{\mathrm{co} 2}$ was observed at ASW levels $<\mathbf{5 0 \%}$. Net canopy $A_{\mathrm{co} 2}$ decreased at higher levels of ASW under the high $T_{a} / V P D$ treatment than at the low $\mathrm{T}_{\mathrm{a}} / \mathrm{VPD}$ treatment. At the elevated $\mathrm{CO}_{2}$ concentration $\left(840 \mu \mathrm{mol} \cdot \mathrm{mol}^{-1}\right)$ net canopy $\mathrm{CO}_{2}$ uptake rates were double those that occurred at ambient $\mathrm{CO}_{2}$ levels and they did not exhibit midday reduction. Our data indicate that, when soil water is not readily available, citrus seedlings are more sensitive to high levels of $T_{\mathrm{a}}$ and VPD which results in reduction of $\mathrm{CO}_{2}$ uptake. The inhibitory effects of elevated VPD and reduced ASW on citrus net $\mathrm{A}_{\mathrm{co} 2}$ were lessened at the elevated atmospheric $\mathrm{CO}_{2}$ level.
\end{abstract}

Commercial cultivation of citrus is extremely successful in subtropical areas where rainfall is seasonal, as well as in semi-arid and arid regions. While irrigation is required under these conditions, the conservative water use characteristics of citrus constitutes an important factor in its successful production in these regions.

Stomatal closure of citrus in response to increasing leaf-to-air humidity differences results in low, often nearly constant, transpiration rates (Kaufmann and Levy, 1976; Sinclair and Allen, 1982; $\mathrm{Vu}$ and Yelenosky, 1988). The response of net $\mathrm{CO}_{2}$ assimilation rate $\left(\mathrm{A}_{\mathrm{CO} 2}\right)$ in citrus under conditions of high temperature, high evaporative demand, and low soil water availability is poorly Net $A_{\mathrm{CO} 2}$ rates of nonstressed citrus are low compared to other woody perennials (Downton et al., 1987; Kriedemann, 1971 ) and they frequently have a midday depression (Sinclair and Allen, 1982; Vu and Yelenosky, 1988). Although transpiration is

Received for publication 24 Jan, 1994. Accepted for publication 17 Oct. 1994. We gratefully acknowledge P.H. Jones, W.W. Wynn, and B.C. Bush for technical assistance and D.V. Calvert and R.R. Pelosi, Univ. of Florida Agricultural Research and Education Center, Fort Pierce, for providing the plant material. This research was supported in part by the U.S.-Israel Binational Agricultural Research and Development Fund (BARD, project \#1-61 5-83) and by a US DOE interagency agreement (DE-AI01-81ER60001 ) to USDA-ARS. Florida Agricultural Experiment Station Journal Series no. R-01777. Mention of trade names or proprietary products is for the convenience of the reader only, and does not constitute endorsement or preferential treatment by USDA-ARS or the Univ. of Florida. The cost of publishing this paper was defrayed in part by the payment of page charges. Under postal regulations, this paper therefore must be hereby marked advertisement solely to indicate this fact.

'Current address: Dept. of Agronomy and Plant Genetics, Univ. of Minnesota, 411 Borlaug Hall, 1991 Buford Circle, St. Paul, MN 55108. controlled primarily by stomatal activity, $\mathrm{A}_{\mathrm{C} 22}$ can also be affected by nonstomatal factors referred to collectively as mesophyll resistance. The potential contribution of nonstomatal factors to midday depression of citrus photosynthesis has been described (Bielorai and Mendel, 1969; Sinclair and Allen, 1982; Vu and Yelenosky, 1988), but little work has been conducted to determine the relative importance of stomatal and nonstomatal factors to low $\mathrm{A}_{\mathrm{CO}_{2}}$ and midday reduction in citrus. This information is needed for development of irrigation practices that conserve water and are noninhibitory to citrus growth. The objective of this study was to identify atmospheric and soil water conditions that contribute to midday depression of $\mathrm{A}_{\mathrm{CO2}}$ in seedlings of two important citrus rootstock.

\section{Materials and Methods}

Two-year-old Carrizo citrange (Poncirus trifoliata x Citrus sinensis) and Swingle citrumelo ( $P$. trifoliata $\times$ C. paradisii) seedlings were grown in a greenhouse in 2-liter metal containers using a loam potting medium. On 9 Apr. 1985, 72 containers of each rootstock cultivar were placed separately in each of two sunlit, computer-controlled environment chambers. The design and verification of the dynamic computer control of these closedcirculation plant growth chambers has been described previously (Allen, 1990; Jones et al., 1984). The canopy in each chamber intercepted nearly all of the incoming radiation as determined with a line quantum sensor (model 191; LI-COR, Lincoln, Neb.) mounted inside each chamber to measure photosynthetic photon flux density (PPFD).

The containers, with holes near the bottom for drainage and 
flood irrigation, were placed in shallow $(1 \times 2 \times 0.15-\mathrm{m})$ galvanized metal trays in the chambers. Irrigation was provided by flooding the trays (when required) for $\approx 2 \mathrm{~h}$ near sunset and allowing them to drain naturally overnight. Two bathroom scales, fitted with linear variable displacement transducers with remote digital readout units, were placed under each metal tray that held the 72 containers and were used to measure daily weight changes of the containers attributable to evapotranspiration. The total available soil water content $\left(\mathrm{ASW}_{\text {tot }}\right.$ ) of containers in each chamber was determined as the weight of the plants plus containers the morning following an irrigation, when soil was assumed to be near field capacity, minus the weight they attained when temporary wilting of leaves occurred. The percentage ASW remaining each morning and earl y evening was determined by subtracting from $\mathrm{ASW}_{\text {tot }}$ the cumulative amount of cooling coil condensate collected in a closed container $\left[\mathrm{ASW}=\left(\mathrm{ASW}_{\text {tot }}-\right.\right.$ total condensate $) /$ $\mathrm{ASW}_{\text {tot }}$ 100]. Reported values represent ASW near sunset.

All plants were about the same size, $1.0 \mathrm{~m}$ high, when the study began. Plants in both chambers produced flushes of growth at the same time. Vertical growth was pruned after each flush so that shoots did not grow against the top of the chamber.

Dry-bulb temperature controls in the chambers were set for a diurnal pattern representative of outdoor conditions. Dry-bulb temperature control was reset each hour during the day and dewpoint temperature (DPT) was essentially constant during a 14$\mathrm{h}$ daytime period beginning at 0600 and ending at $2000 \mathrm{HR}$. Maximum $\mathrm{T}_{\mathrm{a}}$ and constant DPT control set points were 29/14 and $37 / 22 \mathrm{C}$, for the low- and high-temperature levels, respectively; this resulted in maximum daytime vapor-pressure deficits of 2.4 and $3.6 \mathrm{kPa}$. Temperatures maintained in the chambers were typically within 1 to $2 \mathrm{C}$ of the control set points and temperature differences between the two chambers were typically $<1 \mathrm{C}$. Constant nighttime $\mathrm{T}_{2} / \mathrm{DPT}$ controls were set at $16 / 8$ and $22 / 8 \mathrm{C}$, which resulted in overnight (2000 to $0600 \mathrm{HR}$ ) air vapor-pressure deficits of 0.8 and $1.6 \mathrm{kPa}$ for the low- and high-temperature treatments, respectively. Dates and duration of environmental conditions within the chambers are given in Table 1. Environmental treatment conditions were imposed for 2 to 7 days.

The plant growth chambers and control systems provided control of air temperature, vapor pressure (via dewpoint temperature), $\mathrm{CO}_{2}$ concentration, and soil water conditions, as well as continuous measurement of net canopy $\mathrm{A}_{\mathrm{CO} 2}$ and transpiration rates. The length, width, and height dimensions of the chambers were $2.0,1.0$, and $1.5 \mathrm{~m}$, respectively. The east, south, and west walls were constructed of 0.18-mm Mylar polyester film, and the tops were made of $6.35 \mathrm{~mm}$ acrylic plate. About $89 \%$ of solar PPFD was transmitted by the transparent covers. The north wall was constructed of 9.52-mm acrylic plate with outflow and inflow plenums to and from the attached air circulation and conditioning ductwork. Four air-exchanges per minute were provided by impeller fans. A chilled-water heat exchanger in the ductwork condensed water from transpiration and was used to control dewpoint temperature. An electrical resistance heater restored air temperature to the treatment level. Air samples were pumped from each chamber to an adjacent laboratory and were analyzed for dewpoint temperatures (model 110 DP dewpoint hygrometer; General Eastern) and $\mathrm{CO}_{2}$ concentrations (model 865 infrared gas analyzer; Beckman) sequentially over a 300 -sec period. Based on these measurements, adjustments were made to the rate of chilled water flow through the heat exchanger, and to the rate of injection of $\mathrm{CO}_{2}$.

Carbon dioxide injection was executed every $20 \mathrm{sec}$ based on an algorithm using measured solar radiation. This injection rate was adjusted each $300 \mathrm{sec}$ based on measured $\mathrm{CO}_{2}$ concentration within the chambers. Also, the electrical resistance heater was controlled every $20 \mathrm{sec}$ based on measurements of a radiationshielded thermocouple near the top center of the chamber.

Net canopy $A_{\mathrm{C} 22}$ per unit ground area was computed every 300 sec for each chamber based on the amount of $\mathrm{CO}_{2}$ injected, adjusted by the decrease or increase of $\mathrm{CO}_{2}$ concentration inside each chamber. Evapotranspiration rates (ET) per unit ground area were also computed every $300 \mathrm{sec}$ based on tipping bucket raingage measurements of condensate. The $300-\mathrm{sec} \mathrm{A}_{\mathrm{CO} 2}$ and ET values were averaged over hourly intervals. Water-use efficiency (WUE), the ratio of $\mathrm{A}_{\mathrm{CO} 2} / \mathrm{ET}$, was computed for the daytime hourly data. The environmental control system and data logging functions were managed by an ADAC PDP-1623 computer. Further details on operation and use of this system have been previously reported (Baker et al., 1990; Jones et al., 1985).

Treatments consisted of two levels of maximum daily dry-bulb air temperature/vapor-pressure deficit (T/VPD: 29C/2.4 kpa and $37 \mathrm{C} / 3.6 \mathrm{kPa})$ and two levels of atmospheric $\mathrm{CO}_{2}$ concentration (330 and $840 \mu \mathrm{mol} \cdot \mathrm{mol}^{-1}$ ). Treatments were imposed at different times to plants in both chambers. At each treatment level, soil water depletion cycles were imposed by allowing water in the containers to be depleted until leaves began to wilt. The duration of a drying cycle varied according to the temperature and $\mathrm{CO}_{2}$ level. At each combination of two levels of $\mathrm{T}_{\mathrm{a}} / \mathrm{VPD}$ and two levels of $\mathrm{CO}_{2}$ concentration, changes in rates of net canopy $\mathrm{A}_{\mathrm{CO} 2}$ and $\mathrm{ET}$

Table 1. Dates and starting times of environmental conditions, daily maximum dry-bulb temperature, constant dewpoint temperature, and $\mathrm{CO}_{2}$ concentrations in growth chambers during the study period, 10 Apr. to 14 May.

\begin{tabular}{|c|c|c|c|c|}
\hline \multirow[b]{2}{*}{ Date } & \multirow{2}{*}{$\begin{array}{l}\text { Time } \\
(\mathrm{HR})\end{array}$} & \multicolumn{2}{|c|}{ Temp $\left({ }^{\circ} \mathrm{C}\right)$} & \multirow{2}{*}{$\begin{array}{c}\mathrm{CO}_{2} \\
\left(\mu \mathrm{mol} \cdot \mathrm{mol}^{-1}\right)\end{array}$} \\
\hline & & Dry bulb $^{z}$ & Dewpoint & \\
\hline 10-18 Apr. & 0730 & 29 & 14 & 330 \\
\hline 18-21 Apr. & 1530 & 37 & 22 & 330 \\
\hline 2 1-25 Apr. & 1915 & 29 & 14 & 330 \\
\hline 25 Apr. & $1255-1455$ & 37 & 22 & 330 \\
\hline 25 Apr. & $1500-1820$ & 29 & 14 & 330 \\
\hline 25 Apr. & 1825 & 37 & 22 & 330 \\
\hline 29-30 Apr. & 0725 & 37 & 22 & 840 \\
\hline 30 Apr.-4 May & 0800 & 29 & 14 & 840 \\
\hline 4-10 May & 0755 & 37 & 22 & 840 \\
\hline 10-14 May & 1430 & 37 & 22 & 330 \\
\hline
\end{tabular}

${ }^{\bar{T}}$ The dry-bulb temperature setpoints for each hourly interval beginning at $0000 \mathrm{HR}$ were $15,15,15,14,14,14,18,22,24,26,28$, $28,29,29,29,27,25,21,18,17,17,16,16$, and $16 \mathrm{C}$ for the low-temperature treatment. Setpoints for each hourly interval were $8 \mathrm{C}$ higher for the high-temperature treatment. 
were evaluated throughout a soil drying cycle. The dates available for representation of these conditions were limited by variable solar radiation. Data points plotted in the figures for response variables and environmental conditions are the means of the two rootstock cultivars (two chambers), with the range in differences between rootstock (chambers) indicated by vertical bars through each data point. Mean values reported in the remainder of the text refer to the average response of the two cultivars, or to the average of the growth chamber environmental conditions.

\section{Results}

Response to solar radiation. Net plant canopy $\mathrm{CO}_{2}$ uptake rates showed a light compensation point at a PPFD of $\approx 100 \mu \mathrm{mol} \cdot \mathrm{m}^{-2} \cdot \mathrm{s}^{-1}$. Net canopy $\mathrm{CO}_{2}$ uptake rates increased linearly with increasing photosynthetic photon flux density (PPFD) to $\approx 800 \mu \mathrm{mol} \cdot \mathrm{m}^{-2} \cdot \mathrm{s}^{-1}$ and flattened out sharply over the 800 to $1000 \mu \mathrm{mol} \cdot \mathrm{m}^{-2} \cdot \mathrm{s}^{-1}$ range (data not shown).

Atmospheric and soil water effects on diurnal gas exchange at

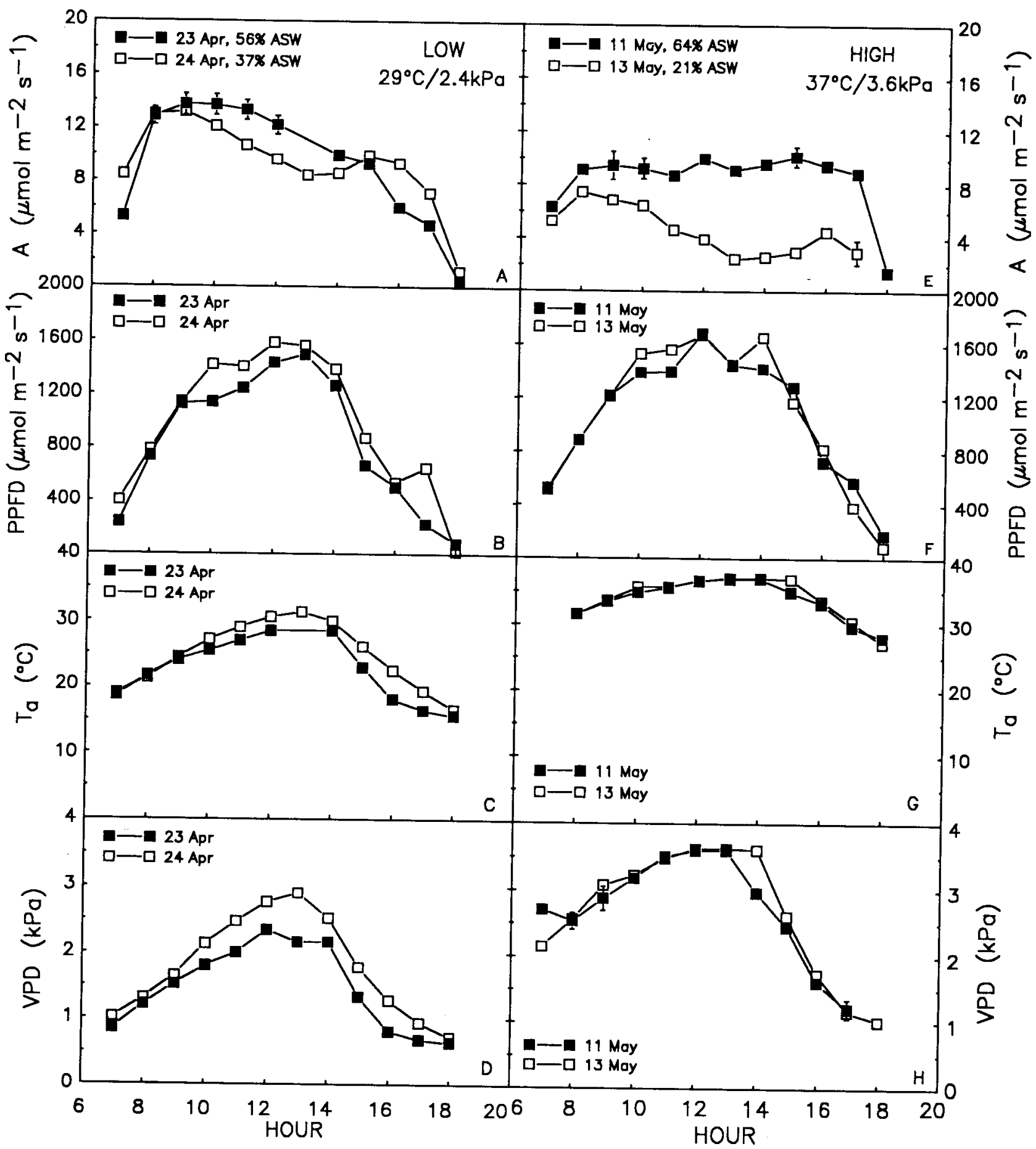

Fig. 1. Hourly average net canopy $\mathrm{CO}_{2}$ assimilation rate (A), photosynthetic photon flux density (PPFD), air dry bulb temperature (Ta), and atmospheric vapor-pressure deficit (VPD) at the low- (A-D) and high-temperature (E-H) levels. High and low available water levels (ASW) at the low-temperature/vapor-pressure deficit level were $56 \%$ and $37 \%$, respectively, and $64 \%$ and $13 \%$, respectively, at the high-temperature/vapor-pressure deficit level. Data points represent the mean of twelve 300 sec interval readings for Swingle citrumelo and Carrizo citrange during the indicated hour, Bars represent the range of differences between the two rootstock. Carbon dioxide concentration is $330 \mu \mathrm{mol} \cdot \mathrm{mol}^{-1}$. 
ambient levels of $\mathrm{CO}_{2}$. A maximum mean net canopy $\mathrm{A}_{\mathrm{CO} 2}$ per unit ground surface area of $14.5 \mu \mathrm{mol} \cdot \mathrm{m}^{-2} \cdot \mathrm{s}^{-1}$ (Fig. 1A) occurred before 1100 HR on 23 Apr. (a relatively clear day, Fig. 1 B) when exposed to the low $(29 \mathrm{C} / 2.4 \mathrm{kPa}) \mathrm{T}_{\mathrm{a}} / \mathrm{VPD}$ treatment (Fig. $1 \mathrm{C}$ and D) and ambient $\left(330 \mu \mathrm{mol} \cdot \mathrm{mol}^{-1}\right) \mathrm{CO}_{2}$ concentration. Rates declined throughout the remainder of the day while solar radiation remained high. Similar trends were observed on other days at this temperature level when soil water was greater than $90 \%$ ASW (data not shown). These net canopy $\mathrm{A}_{\mathrm{CO} 2}$ trends indicate that the citrus seedlings experienced some degree of stress at this $\mathrm{T}_{\mathrm{a}} / \mathrm{VPD}$ level when exposed to ambient levels of $\mathrm{CO}_{2}$. Typically, midday depression of net canopy $\mathrm{A}_{\mathrm{CO} 2}$ was apparent at the low $\mathrm{T}_{\mathrm{a}} / \mathrm{VPD}$ level when soil water contents were below $50 \%$ ASW.

Maximum mean net canopy $\mathrm{A}_{\mathrm{CO} 2}$ at the high $(37 \mathrm{C} / 3.6 \mathrm{kPa}) \mathrm{T}_{\mathrm{a}} / \mathrm{VPD}$ level and soil water content $>50 \%$ ASW was $10.5 \mu \mathrm{mol} \cdot \mathrm{m}^{-2} \cdot \mathrm{s}^{-1}$ and was attained by $0900 \mathrm{HR}$ on 11 May (Fig. $1 \mathrm{E}$ ). Mean canopy $\mathrm{CO}_{2}$ uptake rates remained nearly constant, in the range 9.5 to $10.5 \mu \mathrm{mol} \cdot \mathrm{m}^{-2} \cdot \mathrm{s}^{-1}$, despite increasing PPFD during the day. Net canopy $\mathrm{A}_{\mathrm{c} 2}$ was reduced under the high $\mathrm{T}_{\mathrm{a}} / \mathrm{VPD}$ treatment, compared to rates obtained at the low $\mathrm{T}_{\mathrm{a}}$ VPD level, but midday depression typically was not observed whale the soil water content remained $>50 \%$ ASW. At the low soil water level (21\% ASW) and high T/VPD level, the maximum mean net canopy $\mathrm{A}_{\mathrm{C} 22}$ rate of $7.4 \mu \mathrm{mol} \cdot \mathrm{m}^{-2} \cdot \mathrm{s}^{-1}$ occurred before $0900 \mathrm{HR}$ at a PPFD level of $886 \mu \mathrm{mol} \cdot \mathrm{m}^{-2} \cdot \mathrm{s}^{-1}$. Midday reduction and late afternoon recovery of $\mathrm{CO}_{2}$ uptake rates

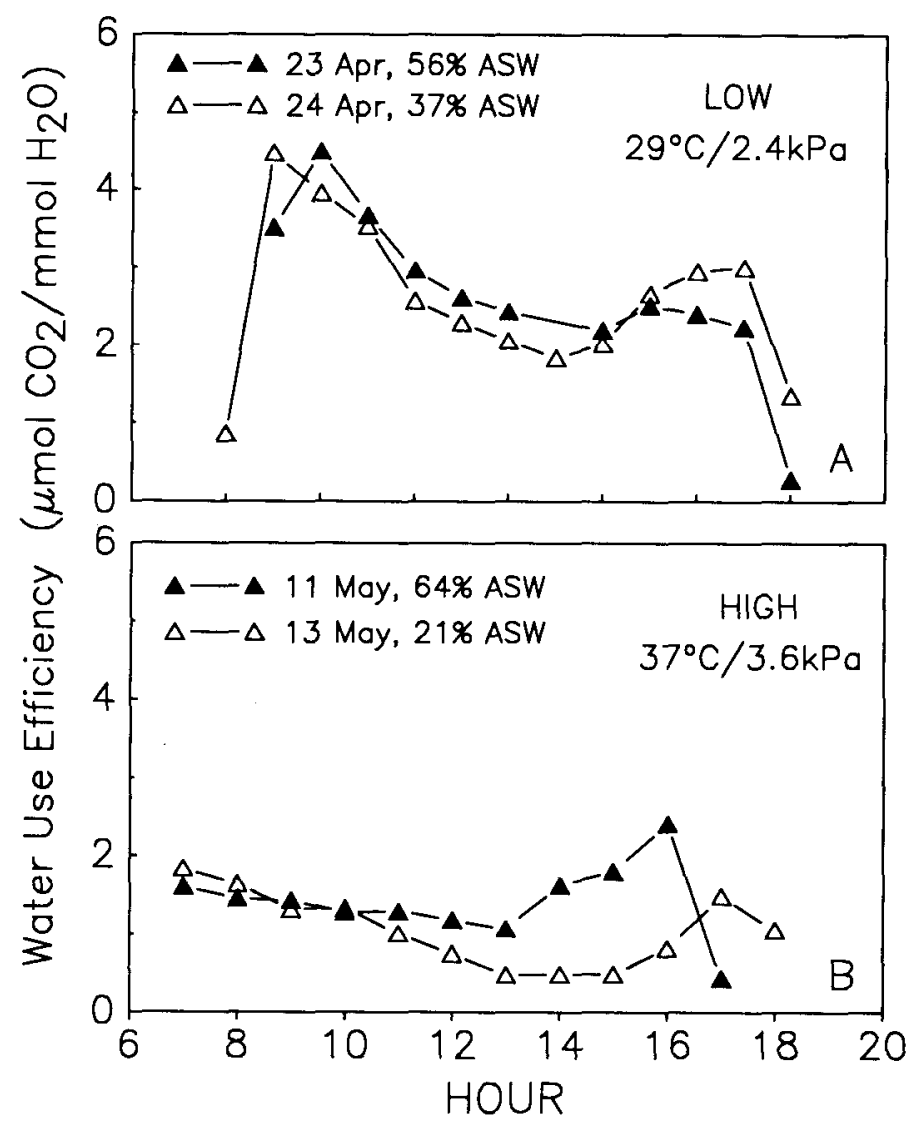

Fig. 2. Water-use efficiency ( $\mu$ mol $\mathrm{CO}_{2}$ uptake/mmol $\mathrm{H}_{2} \mathrm{O}$ loss from plants and containers) of Swingle citrumelo citrus and Carrizo citrange at the low- (A) and high-temperature (B) levels. High and low available water levels (ASW) at the low-temperature/vapor-pressure deficit level were $56 \%$ and $37 \%$, respectively, and $64 \%$ and $13 \%$, respectively, at the high-temperature/vapor-pressure deficit level. Data points represent the mean of twelve 300-sec interval readings for both rootstock during the indicated hour. Carbon dioxide concentration is 330 $\mu \mathrm{mol} \cdot \mathrm{mol}^{-1}$. were typically observed under conditions of high $\mathrm{T}_{\mathrm{a}} / \mathrm{VPD}$ when available soil water fell below $60 \%$.

Between $\mathrm{T}_{\mathrm{a}}$ of 29 to $37 \mathrm{C}$ and VPD of 2.4 to $3.6 \mathrm{kPa}$, the maximum mean net canopy $\mathrm{A}_{\mathrm{C} 02}$ changed about $-0.5 \mu \mathrm{mol} \cdot \mathrm{m}^{-2} \cdot \mathrm{s}^{-1}$ per ${ }^{\circ} \mathrm{C}$ or about $-3.2 \mu \mathrm{mol} \cdot \mathrm{m}^{-2} \cdot \mathrm{s}^{-1}$ per $\mathrm{kPa}$ under conditions when available soil water was $>50 \%$. This decrease with increasing $\mathrm{T}_{\mathrm{a}}$ or VPD shows the effect of the aerial environment on citrus $\mathrm{CO}_{2}$ uptake rates at ambient $\mathrm{CO}_{2}$ level.

The hour-by-hour $\mathrm{CO}_{2}$ uptake rates of the two cultivars were very similar for the 4 days shown in Fig. 1. The vertical bars on each data point show the range of values between the two, paired, hourly measurements. For many cases, the range is hidden by the size of the plotted data points. Taken across these 23 paired, hourly data sets, the summation of the $\mathrm{CO}_{2}$ uptake in the Carrizo citrange chamber was nearly identical to that of Swingle citrumelo, although the maximum deviation was as high as $2.57 \mu \mathrm{mol} \cdot \mathrm{m}^{-2} \cdot \mathrm{s}^{-1}$. Net canopy Ace, remained very similar for the two cultivars for each hour of measurement throughout the entire study period, 10 Apr. to 14 June 1985.

Maximum mean ET (expressed as $\mu$ moles of $\mathrm{H}_{2} \mathrm{O} / \mathrm{m}^{2}$ of ground

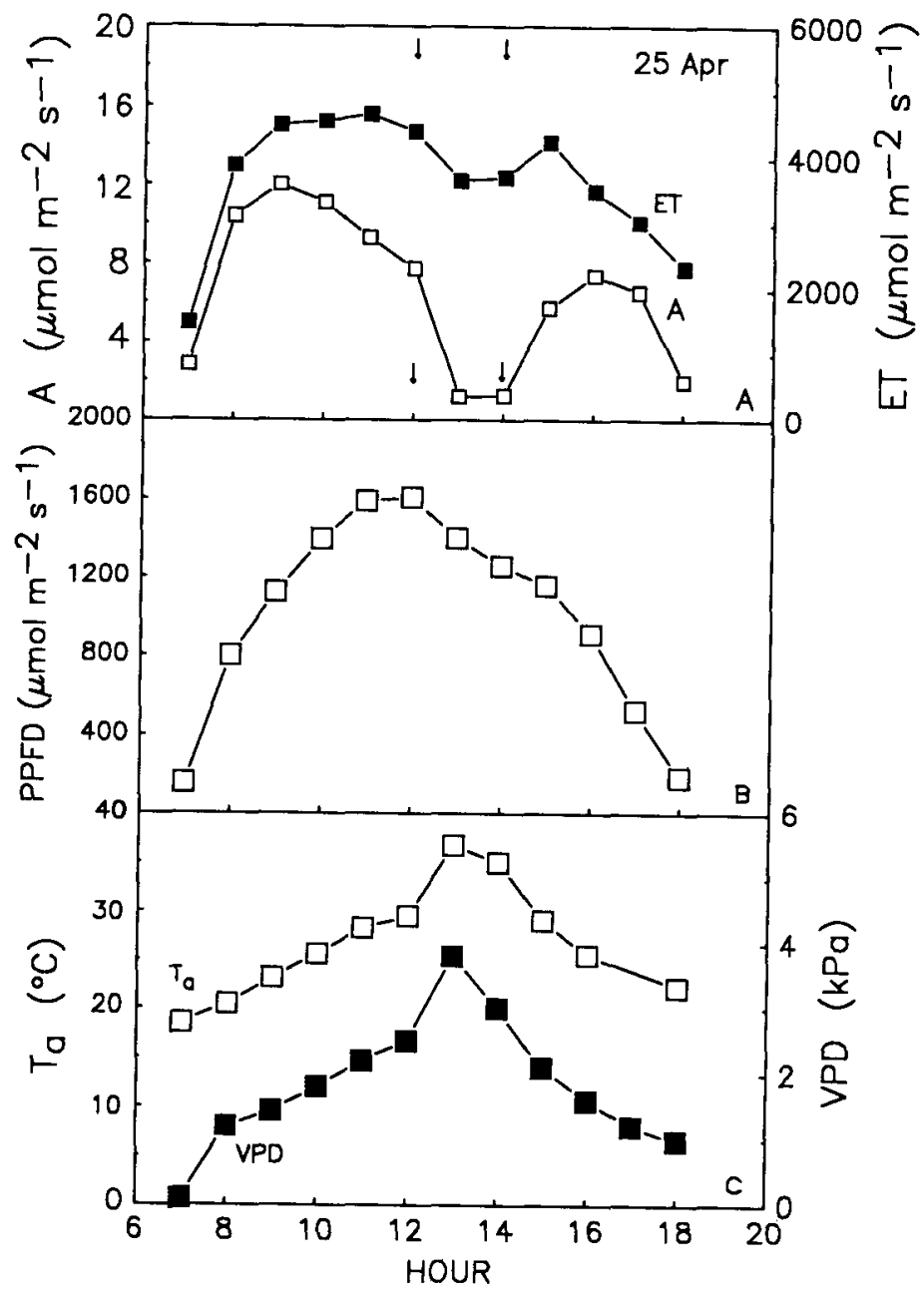

Fig. 3. Hourly average net canopy $\mathrm{CO}_{2}$ assimilation rate (A) and evapotranspiration rate (ET) of Swingle citrumelo citrus seedlings at the low-temperature level with short-term exposure to the high temperature. Arrows indicate the period of elevated dry-bulb temperature. Hourly average photosynthetic photon flux density (PPFD), dry bulb air temperature (Ta) and atmospheric vapor-pressure deficit (VPD) throughout the day (B-D, respectively) are also shown, Data points represent the mean of twelve 300 -sec interval readings during the indicated hour, Carbon dioxide concentration is $330 \mu \mathrm{mol} \cdot \mathrm{mol}^{-1}$. 
surface area/sec) at soil water contents $>50 \%$ ASW (associated with the data of Fig. 1 ) increased from 4980 to $8280 \mu \mathrm{mol} \cdot \mathrm{m}^{-2} \cdot \mathrm{s}^{-1}$ at the low and high $\mathrm{T}_{\mathrm{a}} / \mathrm{VPD}$ treatments, respectively. At low soil water contents ET attained a maximum during the early morning hours and remained nearly constant throughout most of the day as the $\mathrm{T}_{\mathrm{a}} / \mathrm{VPD}$ level increased. At low soil water levels $(<50 \% \mathrm{ASW})$, maximum mean ET values were 4650 and $4770 \mu \mathrm{mol} \cdot \mathrm{m}^{-2} \cdot \mathrm{s}^{-1}$ at the low and high $\mathrm{T}_{\mathrm{a}} / \mathrm{VPD}$ levels, respectively.

High values of WUE occurred at the low $\mathrm{T}_{\mathrm{a}} / \mathrm{VPD}$ during the morning hours, typically before $1000 \mathrm{HR}$ (Fig. 2). Values declined during the middle of the day as a result of decreasing net canopy $\mathrm{A}_{\mathrm{CO} 2}$ accompanied by increasing or steady ET. Water-use efficiency was greatly reduced throughout the day under the high $\mathrm{T}_{\mathrm{a}} /$ VPD conditions at both high and low levels of available soil water compared to values obtained at the low level of $T_{a} / V P D$. Higher WUE values during the late afternoon reflect declining ET resulting from reduced VPDs.

The immediate effects of high $\mathrm{T}_{\mathrm{a}}$ and high VPD on $\mathrm{A}_{\mathrm{C} 22}$ and ET

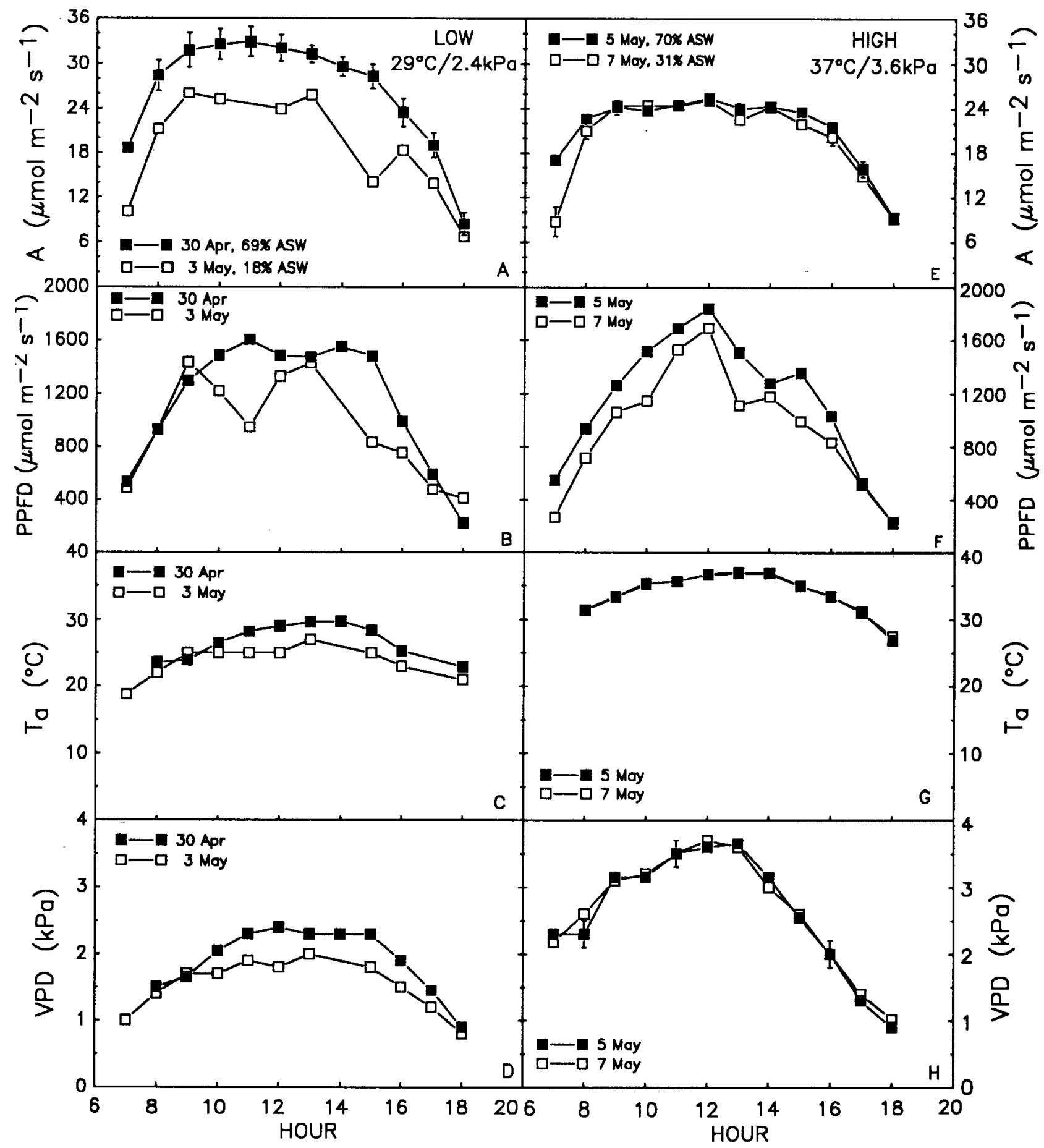

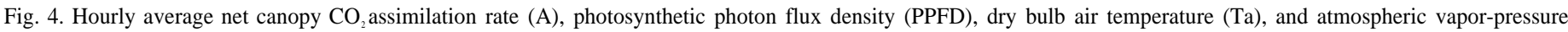

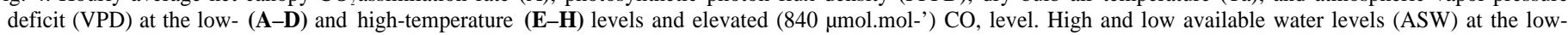

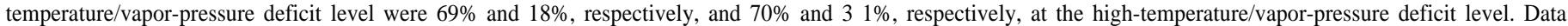

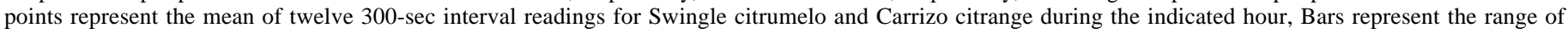
differences between the two rootstock. 
(Fig. 3A) are apparent when T/DPT controls were switched abruptly from 29/ 14C to 37/22C (Fig. 3C) between 1200 and 1400 HR on 25 Apr. Within 10 min of the temperature change, net canopy $\mathrm{A}_{\mathrm{CO} 2}$ of the Swingle citrumelo plants dropped and remained nearly constant at rates less than $1 \mu \mathrm{mol} \cdot \mathrm{m}^{-2} \cdot \mathrm{s}^{-1}$ until temperatures were switched at $1400 \mathrm{HR}$ to their previous levels (Fig. 3A). Carbon dioxide exchange rates of Carrizo citrange fell from 7.6 to 0.8 $\mu \mathrm{mol} \cdot \mathrm{m}^{-2} \cdot \mathrm{s}^{-1}$ within $25 \mathrm{~min}$ of the T/DPT change and were slightly higher than rates for Swingle citrumelo during the period of elevated temperatures (data not shown). In comparison, evapotranspiration rates were less affected by the increased temperature and VPD (Fig. 3C). Carbon dioxide uptake rates attained values nearly equal to those existing before the change within $25 \mathrm{~min}$ of reestablishment of previous temperatures.

Gas exchange under elevated $\mathrm{CO}_{2}$ conditions. Midday depression of net $\mathrm{A}_{\mathrm{CO} 2}$ was not observed in plants subjected to the elevated $\mathrm{CO}_{2}$ concentration $\left(840 \mu \mathrm{mol} \cdot \mathrm{mol}^{-1}\right)$ regardless of $\mathrm{T}_{\mathrm{a}} / \mathrm{VPD}$ level or soil water status (Fig. 4). At the elevated $\mathrm{CO}_{2}$ concentration, maximum mean net canopy $\mathrm{A}_{\mathrm{c} 22}$ values at soil water levels $>50 \%$ ASW were 2-fold greater than the maximum rates that occurred at respective $\mathrm{T}_{2} / \mathrm{VPD}$ levels under the ambient $\mathrm{CO}_{2}$ concentration. At the low $T_{a} / \mathrm{VPD}$ level $(29 \mathrm{C} / 2.4 \mathrm{kpa})$ and high soil water content (69\% $\mathrm{ASW})$, the range of mean net canopy $\mathrm{A}_{\mathrm{cn} 2}$ was 30.0 to 34.8 $\mu \mathrm{mol} \cdot \mathrm{m}^{-2} \cdot \mathrm{s}^{-1}$ between 0800 and $1500 \mathrm{HR}$ and it was reduced to 21.2 to $26.1 \mu \mathrm{mol} \cdot \mathrm{m}^{-2} \cdot \mathrm{s}^{-1}$ when the AS W was $18 \%$ (Fig. $4 \mathrm{~A}$ ). At the high $\mathrm{CO}_{2}$ concentration and $\mathrm{T} / \mathrm{VPD}$ level $(37 \mathrm{C} / 3.6 \mathrm{kPa})$, maximum mean net canopy $\mathrm{A}_{\mathrm{CO} 2}$ at all soil water levels were reduced relative to rates obtained at the low $\mathrm{T}_{\mathrm{a}} / \mathrm{VPD}$ level (Fig. 4E). Maximum mean canopy $\mathrm{A}_{\mathrm{CO2}}$ occurred before $1000 \mathrm{HR}$ under all conditions with nearly constant rates between 1000 and $1500 \mathrm{HR}$.

Evapotranspiration rates at the elevated $\mathrm{CO}_{2}$ concentration and both $\mathrm{T}_{a}$ /VPD levels were comparable in terms of range and diurnal pattern to rates obtained under ambient $\mathrm{CO}_{2}$ conditions (Table 2). Maximum mean WUE was greater at the elevated $\mathrm{CO}_{2}$ concentration than under the ambient concentration. Maximum mean WUE appeared to be affected more by the $\mathrm{T}_{\mathrm{a}} / \mathrm{VPD}$ level than by the soil water level. Water-use efficiency declined during the early morning hours and remained low during the middle of the day before increasing slightly during the late afternoon.

Carbon dioxide uptake during drought cycles. The effect of soil water depletion at each temperature and $\mathrm{CO}_{2}$ concentration combination is summarized by plotting maximum and minimum mean canopy $\mathrm{CO}_{2}$ uptake rates between 1000 and $1500 \mathrm{HR}$ at the daily average $\mathrm{AS}-\mathrm{W}$ level $\left[\left(\mathrm{ASW}_{\text {moming }}+\mathrm{ASW}_{\text {evening }}\right) / 2\right]$ throughout a soil drying cycle (Figs. 5 and 6). Minimum net canopy $\mathrm{A}_{\mathrm{CO} 2}$ rates indicate changes in midday depression that would not be reflected in the maximum values. Daily total PPFD between 0700 and 1900
HR remained high throughout the duration of the drying cycles and thus solar radiation was unlikely to be a limiting factor (Figs. 5 and 6 ). At the Gainesville latitude of $\approx 29.6 \mathrm{~N}$, daylight hours over the period 21 Apr. to 14 May increased from $13 \mathrm{~h}, 3 \mathrm{~min}$ to $13 \mathrm{~h}, 37$ rein, or $\approx 34 \mathrm{~min}$ (derived from List, 1949). This $4 \%$ increase in daylight hours should not have had much influence on maximum or minimum $\mathrm{CO}_{2}$ assimilation rates or the occurrence of midday depression of $\mathrm{CO}_{2}$ uptake rates throughout the study.

Net canopy $\mathrm{A}_{\mathrm{CO} 2}$ rates at the low $\mathrm{T}_{\mathrm{a}} / \mathrm{VPD}$ treatment and ambient $\mathrm{CO}_{2}$ concentration (Fig. 5A) were limited in the early part of the soil drying cycle, probably by previous exposure to the high $\mathrm{T}_{\mathrm{a}} /$ VPD treatment (19,20, and 21 Apr.). Consequently, the maximum mean $\mathrm{CO}_{2}$ uptake rate of $14.5 \mu \mathrm{mol} \cdot \mathrm{m}^{-2} \cdot \mathrm{s}^{-1}$ occurred on the third day of drying ( 23 April) at $\approx 50 \%$ ASW. Net canopy $\mathrm{A}_{\mathrm{C} 22}$ declined slightly on 24 Apr. at $30 \%$ ASW and declined significantly on 25 Apr. at $13.5 \%$ ASW.

At the high $\mathrm{T}_{\mathrm{a}} / \mathrm{VPD}$ treatment and ambient $\mathrm{CO}_{2}$ concentration, mean net canopy Ace, began to decline when ASW reached $40 \%$ and dropped steadily thereafter to $5 \mu \mathrm{mol} \cdot \mathrm{m}^{-2} \cdot \mathrm{s}^{-1}$ at $11 \% \mathrm{ASW}$ on the last day of the drying cycle (Fig. 5B). Maximum daily $\mathrm{A}_{\mathrm{C} 02}$ remained nearly constant to a lower ASW level under the low $\mathrm{T}_{\mathrm{a}} /$ VPD treatment compared to the high $\mathrm{T}_{\mathrm{a}} / \mathrm{VPD}$ treatment, i.e., the reduction in maximum $\mathrm{A}_{\mathrm{C} 2}$ occurred between $48 \%$ and $30 \% \mathrm{ASW}$ at the low $\mathrm{T}_{\mathrm{a}} / \mathrm{VPD}$ level, and between $64 \%$ and $39 \% \mathrm{ASW}$ at the high $\mathrm{T}_{\mathrm{a}} / \mathrm{VPD}$ level.

At the low $\mathrm{T}_{\mathrm{a}} / \mathrm{VPD}$ level and elevated $\mathrm{CO}_{2}$ concentration, the maximum mean net canopy $\mathrm{A}_{\mathrm{C} 22}$ dropped on the third day of the soil drying cycle (Fig. 6A). The large decrease in $\mathrm{A}_{\mathrm{c} 02}$, when available soil was still $>50 \%$, was not associated with an important change in environmental factors. At $20 \%$ available soil water there was no further reduction of $\mathrm{A}_{\mathrm{C} 02}$. At the high $\mathrm{T}_{\mathrm{a}} / \mathrm{VPD}$ level and elevated $\mathrm{CO}_{2}$ concentration, daily maximum mean net canopy $\mathrm{A}_{\mathrm{CO} 2}$ was $\approx 25.0 \mu \mathrm{molm}^{-2} \cdot \mathrm{s}^{-1}$ during the first 4 days until available soil water was depleted to $\approx 30 \%$ (Fig. $6 \mathrm{~B}$ ). Maximum mean $\mathrm{A}_{\mathrm{CO} 2}$ dropped to $\approx 23 \mu \mathrm{mol} \cdot \mathrm{m}^{-2} \cdot \mathrm{s}^{-1}$ on the sixth day when $\approx 5 \%$ of the available soil water remained. Irrigation was applied before midday depression of $\mathrm{A}_{\mathrm{C} 22}$ was observed.

\section{Discussion}

The results of this study indicate that highest citrus canopy $\mathrm{CO}_{2}$ uptake rates at ambient $\mathrm{CO}_{2}$ concentration were obtained at the low $\mathrm{T}_{\mathrm{a}} / \mathrm{VPD}(29 \mathrm{C} / 2.6 \mathrm{kPa})$ level and lowest rates were obtained at the high $(37 \mathrm{C} / 3.6 \mathrm{kPa}) \mathrm{T}_{\mathrm{a}} / \mathrm{VPD}$ level. Low temperature optima for citrus have been reported (Khairi and Hall, 1976a, 1976b; Kriedemann, 1968). Our findings also concur with those of Bielorai and Mendel (1969) and Thompson et al. (1965); as $\mathrm{T}_{\mathrm{a}} / \mathrm{VPD}$

Table 2. Maximum average canopy $\mathrm{CO}_{2}$ assimilation rate, evapotranspiration rate, and water-use efficiency of citrus seedlings in response to drybulb temperature/vapor-pressure deficit level and available soil water at high $\mathrm{CO}_{2}$ concentration $\left(840 \mu \mathrm{mol}^{-} \cdot \mathrm{mol}^{-1}\right)$ and daily maximum photosynthetic photon flux density. Values are from 300-sec measurements. Maximum values of water-use efficiency did not necessarily occur at the same time as maximum values of assimilation or evapotranspiration,

\begin{tabular}{|c|c|c|c|c|}
\hline \multirow[b]{3}{*}{ Date } & \multicolumn{4}{|c|}{ Dry-bulb temp/vapor-pressure deficit } \\
\hline & \multicolumn{2}{|c|}{ Low $(29 \mathrm{C} / 2.4 \mathrm{kPa})$} & \multicolumn{2}{|c|}{$\operatorname{High}(37 \mathrm{C} / 3.6 \mathrm{kpa})$} \\
\hline & 30 Apr. & 3 May & 5 May & 8 May \\
\hline Available soil water $(\%)$ & 69 & 18 & 70 & 13 \\
\hline $\mathrm{CO}_{2}$ assimilation rate $\left(\mu \mathrm{molm}{ }^{-2} \cdot \mathrm{s}^{-1}\right)$ & 34.8 & 26.1 & 25.6 & 21.2 \\
\hline Evapotranspiration $\mu \mathrm{molm}^{-2} \cdot \mathrm{s}^{-1}$ & 5500 & 4800 & 7600 & 4400 \\
\hline
\end{tabular}

${ }^{\overline{2}}$ Carrizo citrange [Poncirus trifoliata Raf $\times$ Citrus sinensis (L.) Osbeck] and Swingle citrumelo (P. trifoliata Raf x C. paradisii Macf.). 
increased, there was a limited increase in transpiration rate and a reduction in $\mathrm{A}_{\mathrm{CO} 2}$ that was attributed to stomatal closure. This feedback response of citrus transpiration to increases in atmospheric humidity deficit has been attributed to stomata] closure in other studies as well (Hall et al., 1975; Kaufmann and Levy, 1976; Sinclair and Allen, 1982).

Under ambient $\mathrm{CO}_{2}$ levels, midday depression of net $\mathrm{CO}_{2}$ uptake rates was not apparent at either $\mathrm{T}_{\mathrm{a}} / \mathrm{VPD}$ treatment at high soil water levels. However, at low soil water contents, midday depression of net $\mathrm{CO}_{2}$ uptake rates occurred at both temperature levels. Daily maximum and minimum net canopy $\mathrm{CO}_{2}$ assimilation plotted over the percentage remaining available soil water throughout various soil water depletion cycles indicated that maximum net $\mathrm{CO}_{2}$ assimilation was reduced at higher soil water levels at the high $\mathrm{T}_{\mathrm{a}} / \mathrm{VPD}$ level compared to the low $\mathrm{T}_{\mathrm{a}} / \mathrm{VPD}$ level. This indicates that there was an increasing sensitivity of citrus net $\mathrm{CO}_{2}$ assimilation rate to soil water depletion as the $\mathrm{T}_{\mathrm{a}} / \mathrm{VPD}$ level increased. Thus. midday depression of net $\mathrm{CO}_{2}$ assimilation in citrus could likely be avoided with timely irrigation practices and that irrigation will become more critical as the atmospheric vaporpressure deficit increases.

At the elevated $\mathrm{CO}_{2}$ level, maximum net canopy $\mathrm{CO}_{2}$ assimilation was reduced slightly by the increase in vapor-pressure deficit, but maximum $\mathrm{CO}_{2}$ assimilation rates remained nearly constant to a much lower soil water content than occurred at the ambient $\mathrm{CO}_{2}$ level. Our study showed that at the elevated $\mathrm{CO}_{2}$ level, midday depression of $\mathrm{CO}_{2}$ uptake at low soil water contents was alleviated under low and high vapor-pressure deficit conditions. An implication of this is reduced sensitivity of stomatal conductance to the

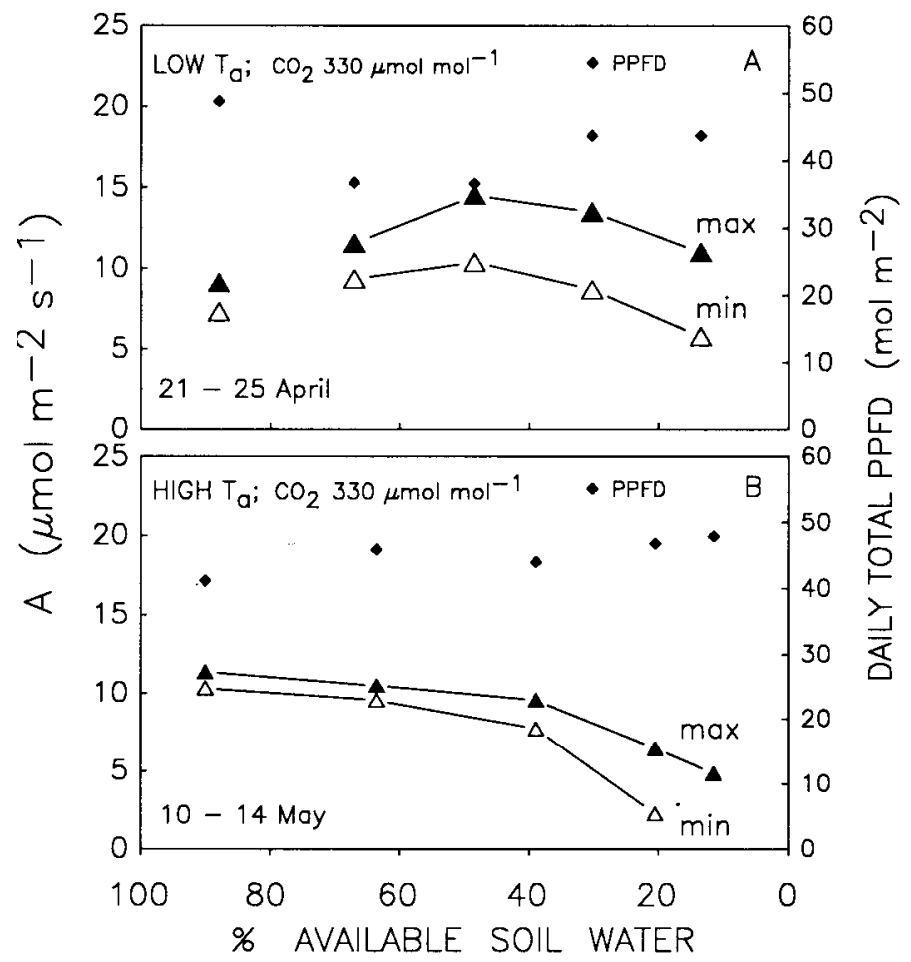

Fig. 5. Hourly maximum and minimum net canopy $\mathrm{CO}_{2}$ assimilation rates (A) of Swingle citrumelo and Carrizo citrange citrus seedlings at the daily average level of available soil water during drying cycles under ambient $\left(330 \mu \mathrm{mol} \cdot \mathrm{mol}^{-1}\right) \mathrm{CO}_{2}$ concentrations at the low- (A) and high-temperature (B) levels. Data points represent the mean of twelve $300-\mathrm{sec}$ interval readings during the indicated hour. In panel $\mathrm{A}$, the chambers were operated at the high-temperature level on the first day (21 Apr.) of the drying cycle. Daily total photosynthetic photon flux density (PPFD) is indicated for each day of the drying cycle by filled diamonds. leaf-to-air vapor-pressure deficit, as has been reported in other studies (Bunce 1993), and to soil water stress. These results suggest that citrus, at higher than ambient levels of $\mathrm{CO}_{2}$, could tolerate some of the adverse effects of high temperature and drought.

Downton et al. (1987) noted that photosynthetic rates of wellwatered citrus plants at $25 \mathrm{C}$ were from 18 to $77 \%$ greater at $\mathrm{CO}_{2}$ concentrations of $800 \mu \mathrm{mol} \cdot \mathrm{mol}^{-1}$ than at $400 \mu \mathrm{mol} \cdot \mathrm{mol}^{-1}$ depending on the developmental stage. A doubling of citrus $\mathrm{CO}_{2}$ assimilation at a $\mathrm{CO}_{2}$ concentration of $840 \mu \mathrm{mol} \cdot \mathrm{mol}^{-2}$ is supported by the results of this study. Subsequently, data collected over a 3-year period ( 1988-90) by Idso and Kimball (1991) on sour orange trees at Phoenix, Ariz., continuously enriched with $300 \mu \mathrm{mol} \cdot \mathrm{mol}^{-1}$ of $\mathrm{CO}_{2}$ above ambient (i.e., $650 \mu \mathrm{mol} \cdot \mathrm{mol}^{-1}$ ), showed 2.2-fold increases in mean $\mathrm{CO}_{2}$ uptake of individual leaves and 2.8-fold increases in mean trunk plus branch volume. The large increase in citrus biomass under $\mathrm{CO}_{2}$ enrichment found by Idso and Kimball (1991) was possible because of continuous incremental crown growth and light capture without mutual shading or competition for water and nutrients by the spaced trees, as well as increased leaf $\mathrm{CO}_{2}$ uptake rates. Allen and Amthor ( 1994) pointed out that, under the climatic conditions of Arizona, leaves of both ambient-air and $\mathrm{CO}_{2}$-enriched grown trees showed midday depression of photosynthesis that persisted throughout the afternoon. Furthermore, the afternoon depression of photosynthesis was much more severe in the ambient-air exposed trees, with leaf $\mathrm{A}_{\mathrm{C} 02}$ being only $\approx 1.2$ $\mu \mathrm{mol} \cdot \mathrm{m}^{-2} \cdot \mathrm{s}^{-1}$, whereas the leaf $\mathrm{A}_{\mathrm{CO} 2}$ was $\approx 4.8 \mu \mathrm{mol} \cdot \mathrm{m}^{-2} \cdot \mathrm{s}^{-1}$ for the enriched trees. These responses of field-grown trees to a hot, high VPD environment are consistent with our data, although we did not see midday depression in our $\mathrm{CO}_{2}$-enriched plants, probably

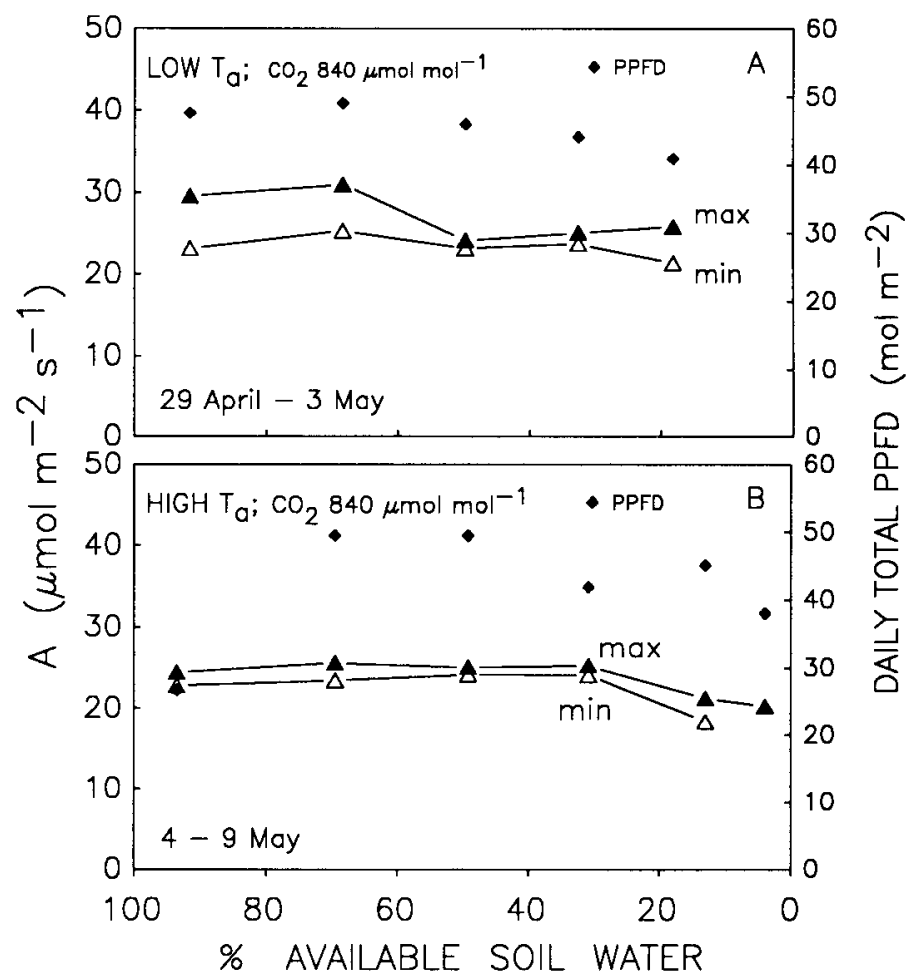

Fig. 6. Hourly maximum and minimum net canopy $\mathrm{CO} 2$ assimilation rates (A) of Swingle citrumelo and Carrizo citrange citrus seedlings at the daily average level of available soil water during drying cycles under elevated $\left(840 \mu \mathrm{mol} \cdot \mathrm{mol}^{-1}\right) \mathrm{CO}_{2}$ concentrations at the low- (A) and high-temperature (B) levels. Data points represent the mean of twelve 300 -sec interval readings during the indicated hour, Daily total photosynthetic photon flux density (PPFD) is indicated for each day of the drying cycle by filled diamonds. 
because our enrichment level was higher and $\mathrm{T}_{\mathrm{A}} / \mathrm{VPD}$ was lower than the field conditions at Phoenix.

The decrease of maximum canopy $\mathrm{CO}_{2}$ uptake rates at the onset of the elevated $\mathrm{CO}_{2}$ treatment could be an example of partial downward regulation (end-product feedback inhibition) of citrus photosynthetic rates in response to a greater photoassimilate supply as has been found in some natural system and crop vegetation (Allen, 1990). Nevertheless, the $\mathrm{CO}_{2}$ uptake rates were still at least 2-fold greater when exposed to these elevated $\mathrm{CO}_{2}$ concentrations, whereas other examples of downward regulation acclimation to elevated $\mathrm{CO}_{2}$ exposure have actually shown a decrease of $\mathrm{CO}_{2}$ uptake rates back to those of the previous lower $\mathrm{CO}_{2}$ exposure levels, or even negative responses to $\mathrm{CO}_{2}$ after a few days.

\section{Literature Cited}

Allen, L. H., Jr. 1990, Plant responses to rising carbon dioxide and potential interactions with air pollutants. J. Environ. Qual. 19: 15-34.

Allen, Jr., L.H. and J.S. Amthor. 1994. Plant physiological responses to elevated $\mathrm{CO}_{2}$, temperature, air pollution, and UV-B radiation. In: G.M. Woodwell and F. Mackenzie (eds.). Biotic feedbacks in the global climatic system: Will the warming increase the warming? IPCC Working Group I Intl. Workshop, 25-29 Oct. 1992, The Woods Hole Research Center, Woods Hole, Mass. Oxford Univ. Press. (In Press. )

Baker, J. T., L.H. Allen, Jr., K.J. Boote, J.W. Jones, and P. Jones. 1990. Rice photosynthesis and evapotranspiration in subambient, ambient, and superambient carbon dioxide concentration. Agron. J. 82:834-840.

Bielorai, H. and K. Mendel. 1969. The simultaneous measurement of apparent photosynthesis and transpiration of citrus seedlings at different soil moisture levels. J. Amer. Sot. Hort. Sci. 94:201-204.

Bunce, J. A. 1993. Effects of doubled atmospheric carbon dioxide concentration on the responses of assimilation and conductance to humidity. Plant Cell Environ. 16: 189-1 97.

Downton, W. J. S., W.J.R. Grant, and B.R. Loveys. 1987. Carbon dioxide enrichment increases yield of Valencia orange. Austral. J. Plant. Physiol.
14:493-501.

Hall, A. E., S.E. Camacho-B, and M.R. Kaufmann. 1975. Regulation of water loss by citrus leaves. Physiol. Plant. 33:62-65.

Idso, S.B. and B.A. Kimball. 1991. Downward regulation of photosynthesiss and growth at high $\mathrm{CO}$, levels. No evidence for either phenomenon in three-year study of sou orange trees. Plant Physiol. 96:990-992.

Jones, P. H., J.W. Jones, L.H. Allen, Jr., and J.W. Mishoe. 1984. Dynamic computer control of closed environmental plant growth chambers. Design and verification. Trans. Amer. Sot. Agr. Eng. 27:879-888.

Jones, P., L.H. Allen, Jr., J.W. Jones, and R. Vane. 1985. Pbotosynthesis and transpiration responses of soybean canopies of short- and long-term CO, treatments. Agron. J. 77: 119-1 26.

Kaufmann, M.R. and Y. Levy. 1976. Stomatal response of Citr-usjambhiri to water stress and humidity, Physiol. Plant. 38: 105-108.

Khairi, M.M. and A.E. Hall. 1976a. Temperature and humidity effects on net photosynthesis and transpiration of citrus. Pbysiol. Plant. 36:29-34.

Khairi, M.M. and A.E. Hall. 1976b. Comparative studies of net photosynthesis and transpiration of some citrus species and relatives. Physiol. Plant. 36:35-39.

Kriedemann, P.E. 1968. Some photosynthetic characteristics of citrus leaves. Austral. J. Biol. Sci. $21: 895-905$.

Kriedemann, P.E. 1971. Photosynthesis and transpiration as a function of gaseous diffusive resistances in orange leaves. Physiol. Plant. 24:21 8-225.

List, R.J. (cd.). 1949. Smithsonian meteorological tables. 6th ed. Smithsonian miscellaneous collections. vol. 114. Smithsonian Institution Press, Washington, D.C.

Sinclair, T.R. and L.H. Allen, Jr. 1982. Carbon dioxide and water vapor exchange of leaves on field-grown citrus trees. J. Expt. Bet. 33:11661175 .

Thompson, I. R., L.H. Stolzy, and O.C. Taylor. 1965. Effect of soil suction, relative humidity and temperature on apparent photosynthesis and transpiration of rough lemon (Citi-usjambhiri). Proc. Amer. Sot. Hort. Sci. 87:168-175.

Vu, J.C.V. and G. Yelenosky. 1988. Water deficit and associated changes in some photosynthetic parameters in leaves of 'Valencia' orange (Citrus sinensis [L.] Osbeck). Plant Physiol. 88:375-378. 